\title{
Analisis Pengaruh Kurs USD terhadap Jakarta Islamic Index dengan Menggunakan Model Fungsi Transfer
}

\author{
Pika Silvianti*, Nur Laela Fitriani* \\ *Departemen Statistika Institut Pertanian Bogor
}

\begin{abstract}
Abstrak-The transfer function model is a time series forecasting model that combines several characteristics of the ARIMA model one variable with several characteristics of regression analysis. This model is used to determine the effect of an explanatory variable (input series) on the response variable (output series). This study uses a transfer function model to analyze the effect of the exchange rate on Jakarta Islamic Index. The transfer function model is structured through several stages, starting from model identification, estimation of the transfer function model, and model diagnostic testing. Based on the transfer function model, Jakarta Islamic Index was influenced by Jakarta Islamic Index in one and two days earlier and the exchange rate in the same period and one to two days earlier. The forecasting MAPE value of $\mathbf{0 . 6 5 2 9} \%$ shows that the transfer function model obtained is good enough in forecasting.

Kata kunci-ARIMA; model fungsi transfer; Jakarta Islamic Index; prewhitening
\end{abstract}

\section{PENDAHULUAN}

\section{A. Latar Belakang}

Pertumbuhan ekonomi suatu negara dapat dilihat melalui beberapa indikator. Salah satu indikator yang paling sering digunakan adalah pasar modal. disini, berbagai instrumen keuangan jangka panjang dapat diperjual belikan. Mulai dari obligasi, saham, reksa dana, maupun instrumen keuangan lainnya. Sebagai negara dengan mayoritas penduduk muslim, Indonesia membutuhkan produk syariah untuk mengakomodasi investasi dengan prinsip syariah. BEI bekerja sama dengan PT Danareksa Investment Management pada tanggal 3 Juli 2000 membentuk Jakarta Islamic Index (JII). JII memiliki kinerja yang baik dibandingkan dengan indeks saham lainnya dan semakin menguat pada tahun 2014 dengan mengacu pada tiga puluh saham yang usahanya memenuhi prinsip syariah Islam. Investor dapat menggunakan JII sebagai indikator untuk mengukur kinerja investasi di saham-saham syariah (BEI 2010).

Peramalan JII dapat menggunakan model deret waktu, namun pengaruh peubah penjelas terhadap peubah respon dapat juga dipertimbangkan dalam peramalannya. Model fungsi transfer merupakan suatu model peramalan deret waktu berganda yang menggabungkan beberapa karakteristik modelmodel ARIMA satu peubah dengan beberapa karakteristik analisis regresi. Model ini dapat digunakan untuk menganalisis faktor-faktor yang memengaruhi Jakarta Islamic Index salah satunya nilai kurs atau nilai tukar USD terhadap rupiah. Menurut Yulanda (2006) hasil analisis dengan menggunakan model fungsi transfer menyatakan bahwa nilai tukar rupiah memengaruhi indeks harga saham Indonesia. Oleh karena itu, peneliti tertarik untuk melakukan penelitian ini menggunakan pendekatan model fungsi transfer untuk melihat besar pengaruh nilai kurs terhadap Jakarta Islamic Index (JII).

\section{B. Tujuan}

Tujuan Tujuan dari penelitian ini yaitu menerapkan model fungsi transfer pada pemodelan Jakarta Islamic Index dengan deret input kurs Rupiah terhadap USD.

\section{TINJAUAN PUSTAKA}

\section{A. Jakarta Islamic Index}

Jakarta Islamic Index atau biasa disebut dengan JII merupakan indeks harga saham syariah yang dikeluarkan oleh Bursa Efek Indonesia (BEI) dan mampu menggambarkan kinerja saham syariah di Indonesia. Hari dasar yang digunakan untuk menghitung JII adalah tanggal 2 Januari 1995 dengan angka indeks dasar sebesar 100 sehingga dapat 
menghasilkan data historikal yang lebih panjang (BEI 2010). Semua saham syariah yang terdapat di pasar modal syariah Indonesia, baik yang tercatat di BEI maupun tidak, dimasukkan ke dalam Daftar Efek Syariah (DES) yang diterbitkan oleh OJK secara berkala, setiap bulan Mei dan November. Saat ini, kriteria seleksi saham syariah oleh OJK adalah sebagai berikut;

1) Emiten tidak melakukan kegiatan usaha sebagai berikut:

a) Perjudian dan permainan yang tergolong judi;

b) Perdagangan yang dilarang menurut syariah, antara lain:

- Perdagangan yang tidak disertai dengan penyerahan barang/jasa;

- Perdagangan dengan penawaran/permintaan palsu;

c) Jasa keuangan ribawi, antara lain:

- Bank berbasis bunga;

- Perusahaan pembiayaan berbasis bunga;

d) Jual beli risiko yang mengandung unsur ketidakpastian (gharar) dan/atau judi (maisir), antara lain asuransi konvensional;

e) Memproduksi, mendistribusikan, memperdagangkan, dan/atau menyediakan antara lain:

- Barang atau jasa haram zatnya (haram li-dzatihi);

- Barang atau jasa haram bukan karena zatnya (haram lighairihi) yang ditetapkan oleh DSN MUI;

- Barang atau jasa yang merusak moral dan/atau bersifat mudarat;

f) Melakukan transaksi yang mengandung unsur suap (risywah); dan

2) Emiten memenuhi rasio-rasio keuangan sebagai berikut:

a) Total utang yang berbasis bunga dibandingkan dengan total aset tidak lebih dari 45\%; atau

b) Total pendapatan bunga dan pendapatan tidak halal lainnya dibandingkan dengan total pendapatan usaha (revenue) dan pendapatan lain-lain tidak lebih dari $10 \%$

\section{B. Kestasioneran Data Deret Waktu}

Data deret waktu dikatakan stasioner apabila perilaku data tersebut berfluktuasi di sekitar nilai tengah dan ragam yang relatif konstan untuk seluruh periode waktu (Montgomery 2008). Kestasioneran data deret waktu dapat dilihat dari plot deret waktu, plot ACF dan PACF, atau menggunakan uji formal. Pengujian kestasioneran data dapat dilakukan menggunakan uji Augmented Dickey Fuller (ADF). Persamaan model nilai uji akar unit dapat dijelaskan dengan model nilai rataan nol (zero mean) sebagai berikut (Rusdi 2011):

$$
y_{t}=a y_{t}+\epsilon_{t}
$$

Hipotesis yang digunakan untuk uji ADF ini yaitu (Rusdi 2011):

$H_{0}: a=1$, data tidak stasioner

$H_{1}:|a|<1$, data stasioner

Statistik uji t yang digunakan adalah sebagai berikut:

$$
t_{\text {hit }}=\frac{\hat{a}-1}{s d(\hat{a})}
$$

Keterangan:

$y_{t}:$ amatan pada waktu ke-t

$\hat{a}$ : penduga kuadrat terkecil dari a;

se $(\hat{a}:$ standar deviasi dari $\hat{a}$;

$\epsilon_{t}$ : sisaan pengamatan ke-t

Tolak $H_{0}$ jika nilai $t_{\text {hit }}>$ nilai kritis statistik-t. Terima $H_{0}$ jika nilai $t_{\text {hit }}<$ nilai kritis statistikt. Data yang tidak stasioner berdasarkan hasil uji ADF dilakukan pembedaan supaya data menjadi stasioner (Cryer dan Chan 2008).

\section{Autoregressive Integrated Moving Average} (ARIMA)

Autoregressive Integrated Moving Average (ARIMA) merupakan gabungan dari model $\operatorname{ARMA}(p, q)$ dan proses differencing, sehingga secara umum model ini dinotasikan dengan $\operatorname{ARIMA}(\mathrm{p}, \mathrm{d}, \mathrm{q})$. bentuk dari model ini yaitu (Montgomery 2008):

$$
\Phi_{p}(B)(1-B)^{d} Y_{t}=\theta_{q}(B) \alpha_{t}
$$


Keterangan:

$Y_{t}:$ nilai pengamatan pada waktu ke-t;

$\phi_{p}$ : koefisien AR pada ordo ke-p;

$\theta_{q}$ : koefisien MA pada ordo ke-q;

$(1-B)^{d}$ : operator pembeda ordo d;

$\alpha_{t}$ : sisaan pada waktu ke-t;

Pembentukan model ARIMA dilakukan melalui tiga tahapan berikut (Montgomery 2008):

a) Identifikasi model ARIMA.

b) Pendugaan parameter model.

c) Diagnostik model.

\section{Kriteria Pemilihan Model}

Model terbaik merupakan model dengan nilai Schwarz Bayesian Information Criterion (SBC) minimum. SBC didefinisikan sebagai berikut (Cryer dan Chan 2008):

$$
S B C=n \ln \left(\hat{\sigma}_{\alpha}^{2}\right)+M \ln n
$$

Keterangan:

$\hat{\sigma}_{\alpha}^{2}$ : penduga dari $\sigma_{\alpha}^{2}$

$n$ : banyaknya sisaan yang dapat dihitung dari suatu deret;

$M$ : banyaknya parameter;

Kriteria pemilihan model terbaik berdasarkan ketepatan peramalan untuk data validasi menggunakan nilai Mean Absolute Percentage Error (MAPE). Semakin kecil nilai MAPE menunjukkan data hasil peramalan yang semakin mendekati nilai aktual sehingga model yang dipilih merupakan model dengan nilai MAPE terkecil. Nilai MAPE dapat dihitung dengan menggunakan rumus berikut (Montgomery 2008):

$$
M A P E=\frac{\sum_{t=1}^{T}\left|\left(y_{t}-\hat{y}_{t}\right) / y_{t}\right|}{T} x 100
$$

Keterangan:

$y_{t}:$ nilai pengamatan pada waktu ke-t;

$\hat{y}_{t}$ : nilai dugaan pada waktu ke-t;

$T$ : banyaknya data pengamatan;

\section{E. Model Fungsi Transfer}

Tujuan pemodelan fungsi transfer adalah menetapkan model yang sederhana yang menghubungkan $y_{t}$ dengan $x_{t}$ dan $n_{t}$. Pembentukan model fungsi transfer dilakukan melalui beberapa tahap yaitu tahap identifikasi model, pendugaan model fungsi transfer, dan pengujian diagnostik model. Model fungsi transfer secara umum dilambangkan sebagai berikut (Wei 2008):

$$
y_{t}=v(B) x_{t}+n_{t}
$$

Keterangan:

$y_{t}:$ deret output;

$x_{t}:$ deret input;

$n_{t}$ : pengaruh kombinasi dari seluruh faktor yang memengaruhi $y_{t}$ (noise);

$v(B)$ : response impulse, koefisien pada model fungsi transfer;

Penyusunan model fungsi transfer dapat dilakukan melalui tahapan sebagai berikut:

a) Identifikasi model fungsi transfer. Tahap-tahap identifikasi model fungsi transfer yaitu sebagai berikut (Wei 2008):

i) Membuat deret input menjadi white noise, dinotasikan dengan $\alpha_{t}$ dengan persamaan:

$$
\alpha_{t}=\frac{\Phi_{x}(B)}{\theta_{x}(B)} x_{t}
$$

ii) Menghitung deret output dengan membuatnya menjadi white noise dengan model:

$$
\beta_{t}=\frac{\Phi_{x}(B)}{\theta_{x}(B)} y_{t}
$$

iii) Menghitung nilai korelasi silang contoh antara $\alpha_{t}$ dan $\beta_{t}$ pada lag ke-k adalah:

$$
r_{\alpha \beta}(k)=\frac{c_{\alpha \beta}(k)}{S_{\alpha} S_{\beta}}
$$

Keterangan:

$r_{\alpha \beta}(k)$ : korelasi silang antara $\alpha_{t}$ dan $\beta_{t}$ pada lag ke-k;

$c_{\alpha \beta}(k)$ : peragam silang antara $\alpha_{t}$ dan $\beta_{t}$ pada lag ke-k;

$S_{\alpha}$ : simpangan baku deret $\alpha_{t}$; 
$S_{\beta}$ : simpangan baku deret $\beta_{t}$;

iv) Menentukan konstanta $\mathrm{b}, \mathrm{r}$, dan $\mathrm{s}$ berdasarkan pola fungsi korelasi silang antara $\alpha_{t}$ dan $\beta_{t}$.

v) Pendugaan awal parameter model fungsi transfer

b) Pendugaan akhir parameter model kombinasi fungsi transfer galat secara iteratif.

c) Pengujian diagnostik model fungsi transfer sebagai berikut (Wei 2008):

i) Pemeriksaan autokorelasi sisaan model.

ii) Pemeriksaan korelasi silang sisaan dengan masing-masing input prewhitening.

\section{METODOLOGI}

\section{A. Data}

Penelitian ini menggunakan data yang diperoleh dari investing.com. Data yang digunakan merupakan data harian periode 1 Januari 2016 sampai dengan 31 Desember 2017 yang terdiri dari Jakarta Islamic Index (JII) sebagai deret output $\left(y_{t}\right)$ dan kurs $\left(x_{t}\right)$ sebagai deret input.

\section{B. Prosedur Analisis Data}

Metode analisis data yang digunakan dalam penelitian ini adalah sebagai berikut:

a) Mempersiapkan deret output Jakarta Islamic Index (JII) dan deret input kurs.

b) Membagi data menjadi dua bagian, yaitu 436 data pemodelan dan 48 data validasi model.

c) Melakukan eksplorasi data deret input dan data deret output.

d) Melakukan identifikasi plot data deret waktu, ACF, dan PACF dari deret input dan output untuk melihat kestasioneran data. Apabila data belum stasioner dalam rataan maka dilakukan pembedaan, sedangkan apabila tidak stasioner dalam ragam maka dilakukan transformasi.

e) Menentukan model ARIMA untuk data deret input. f) Melakukan uji diagnostik model dengan memenuhi asumsi white noise dan kenormalan.

g) Pemilihan model terbaik berdasarkan nilai SBC terkecil.

h) Melakukan prewhitening pada deret input untuk memperoleh $\alpha_{t}$.

i) Melakukan prewhitening pada deret output untuk memperoleh $\beta_{t}$.

j) Menghitung korelasi silang antara deret input dan output yang telah melalui proses prewhitening.

k) Menetapkan nilai (b,s,r) yang menghubungkan deret input dan output untuk menduga model fungsi transfer.

1) Pendugaan parameter model fungsi transfer awal.

m) Identifikasi model ARIMA deret sisaan.

n) Pendugaan parameter model fungsi transfer akhir.

o) Uji diagnostik model fungsi transfer dengan menghitung autokorelasi sisaan model dan menghitung korelasi silang antara nilai sisaan dengan deret input $\left(\alpha_{t}\right)$ yang telah melalui proses prewhitening.

p) Meramalkan saham untuk kurun waktu 20 Oktober 2017 sampai dengan 31 Desember 2017 menggunakan model fungsi transfer serta menghitung nilai MAPE.

\section{HASIL DAN PEMBAHASAN}

\section{A. Eksplorasi Data}

Eksplorasi data dilakukan untuk melihat gambaran umum mengenai data yang digunakan. Eksplorasi data dilakukan dengan melihat plot data Jakarta Islamic Index (JII) dan kurs yang terdiri dari 484 titik data. Sumbu X menunjukkan periode data sedangkan sumbu Y menunjukkan nilai masing-masing amatan. Berdasarkan plot data JII pada Gambar 1 menunjukkan data berfluktuasi dan cenderung memiliki tren naik. Data terlihat tidak stasioner dalam ragam maupun rataan. Nilai tertinggi JII terjadi pada periode ke-361 dengan nilai amatan sebesar Rp 764.63. Sedangkan 


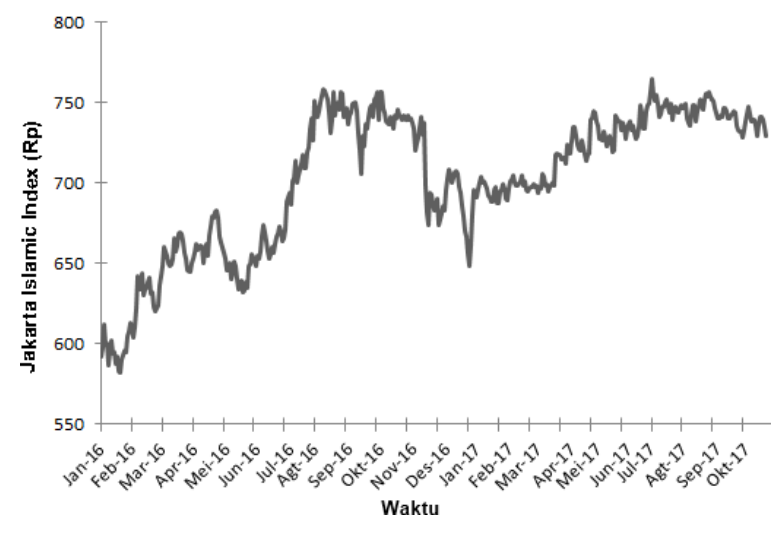

Gambar 1. Plot data deret output Jakarta Islamic Index

nilai amatan terendah JII terjadi pada periode ke-14 dengan nilai amatan sebesar Rp 581.78. JII memiliki kinerja yang cenderung positif. Hal tersebut ditunjukkan dengan adanya pola tren naik pada plot data JII.

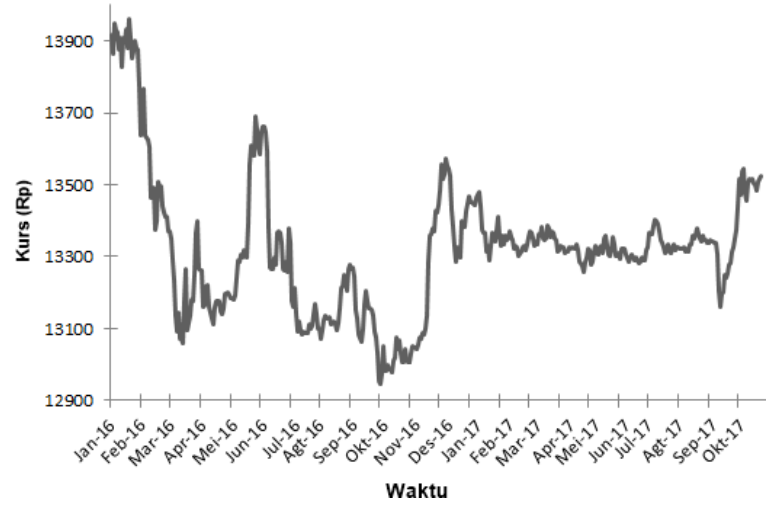

Gambar 2. Plot data deret input kurs

Berdasarkan Gambar 2, plot data kurs terlihat berfluktuasi. Data terlihat tidak stasioner dalam ragam maupun rataan. Nilai tertinggi kurs terjadi pada periode ke-13 yaitu pada tanggal 20 Januari 2016 dengan nilai amatan sebesar Rp13 960. Sedangkan nilai kurs terendah terjadi pada periode ke-181 dengan nilai amatan Rp12 947.5. Sepanjang tahun 2016 data sangat berfluktuasi namun pada tahun 2017 kurs cenderung stabil.

\section{B. Kestasioneran Data}

Hasil pemeriksaan kestasioneran kurs sebagai deret input menunjukkan data belum stasioner dalam ragam dan rataan. Pengujian kestasioneran data secara eksplorasi dapat dilihat dari plot data deret waktu serta plot ACF dan PACF. Plot ACF menujukkan pola tails off secara perlahan namun pola cuts off ditunjukkan pada plot PACF sehingga dapat dikatakan bahwa data belum stasioner.

Tabel I

HASIL UJI ADF

\begin{tabular}{lcc}
\hline Deret Input & $\mathrm{d}=0$ & $\mathrm{~d}=1$ \\
\hline $\operatorname{Kurs}\left(X_{t}\right)$ & 0.0732 & $<0.01$ \\
\hline
\end{tabular}

Plot data kurs menunjukkan data belum stasioner dalam ragam sehingga dilakukan transformasi dalam bentuk logaritma natural. Pengujian Augmented Dickey-Fuller juga dilakukan untuk menguji kestasioneran data. Pengujian Augmented Dickey-Fuller pada Tabel 1 menunjukkan hasil bahwa deret input tidak stasioner dalam rataan karena dihasilkan nilai $p$-value yang lebih besar dari nilai taraf nyata 0.05 sehingga data dilakukan pembedaan. Pembedaan satu kali dilakukan dan menghasilkan data sudah stasioner serta plot ACF dan PACF menunjukkan pola cuts off. Hasil uji Augmented Dickey-Fuller diperoleh nilai $p$-value $<0.01$ lebih kecil dari nilai taraf nyata 0.05 sehingga dapat disimpulkan bahwa data kurs sudah stasioner.

\section{Pembentukan Model ARIMA $(p, d, q)$ Deret Input Kurs $\left(X_{t}\right)$}

Model ARIMA tentatif terbaik yaitu model dengan nilai penduga parameter yang berbeda nyata dengan nol dan hasil uji Ljung-Box yang menunjukkan nilai $p$-value lebih besar dari taraf nyata 0.05 . Selain itu model ARIMA tentatif terbaik dipilih dari model dengan nilai SBC terkecil.

Berdasarkan Gambar 3, plot ACF menunjukkan deret input kurs nyata pada lag ke-1 dan pada plot PACF menunjukkan nyata pada lag ke-1. Hasil identifikasi model ARIMA tersebut dapat dilihat pada Tabel 1 .

Tabel 2 menunjukkan model $\operatorname{ARIMA}(2,1,2)$ memiliki koefisien yang signifikan pada taraf nyata 0.05 . Hasil uji Ljung-Box menunjukkan 

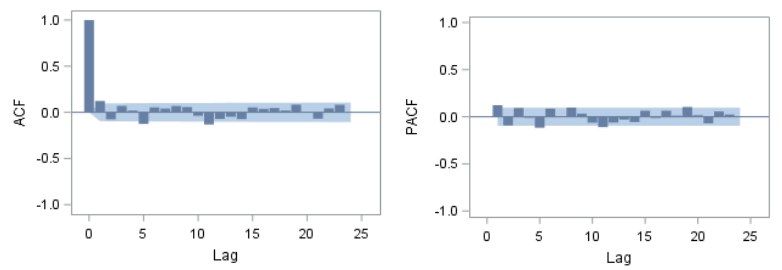

Gambar 3. Plot ACF dan PACF data deret input kurs yang stasioner

Tabel II

NILAI DUGAAN PARAMETER IDENTIFIKASI MODEL SEMENTARA DERET INPUT KURS

\begin{tabular}{ccccc}
\hline Model & Tipe & Koefisien & $p$-value & SBC \\
\hline ARIMA(2,1,2) & AR(1) & -1.4707 & $<0.0001$ & -3783.31 \\
& AR(2) & -0.6384 & $<0.0001$ & \\
& MA(1) & -1.6387 & $<0.0001$ & \\
& MA(2) & -0.6384 & $<0.0001$ & \\
\hline
\end{tabular}

bahwa model ARIMA(2,1,2) memiliki nilainilai yang tidak signifikan pada taraf nyata 0.05 untuk lag 6, 18, dan 24. Hal tersebut menunjukkan bahwa model $\operatorname{ARIMA}(2,1,2)$ tidak memiliki autokorelasi antar sisaan sehingga memenuhi asumsi white noise. Model $\operatorname{ARIMA}(2,1,2)$ memiliki nilai SBC sebesar 3783.31.

\section{Prewhitening Deret Input dan Deret Out- put}

Proses prewhitening deret input dilakukan menggunakan model ARIMA yang sudah terbentuk. Tahap ini menggunakan unsur white noise model tersebut. Proses ini digunakan sebagai dasar perhitungan korelasi silang deret input dan deret output. Model prewhitening terbaik yang terbentuk untuk deret input $\left(X_{t}\right)$ yaitu:

$$
\alpha_{t}=\frac{\left(1+1.4707 B+0.6384 B^{2}\right) X_{t}}{\left(1+1.6387 B+0.6384 B^{2}\right)}
$$

Persamaan model prewhitening deret output JII $\left(Y_{t}\right)$ berdasarkan deret input kurs $\left(X_{t}\right)$ yang terbentuk yaitu:

$$
\beta_{t}=\frac{\left(1+1.4707 B+0.6384 B^{2}\right) Y_{t}}{\left(1+1.6387 B+0.6384 B^{2}\right)}
$$

\section{E. Korelasi Silang}

Hasil perhitungan korelasi silang menunjukkan hasil yang signifikan dengan $p$-value lebih kecil dari nilai taraf nyata 0.05 . Sehingga dapat disimpulkan bahwa terdapat korelasi silang antara $\alpha_{t}$ dan $\beta_{t}$.

\section{F. Identifikasi Model Fungsi Transfer Awal}

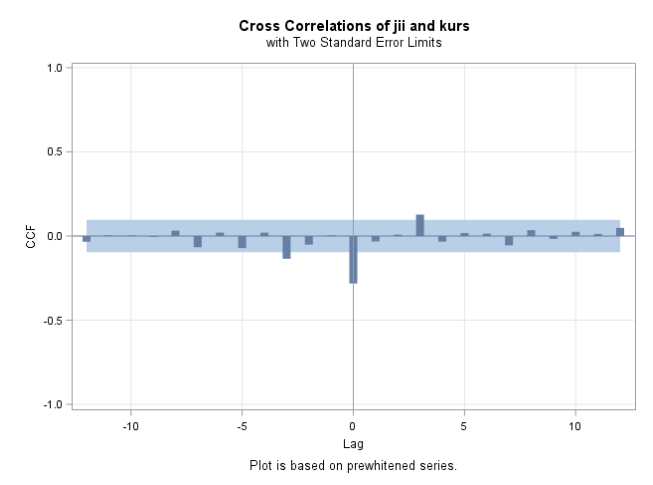

Gambar 4. Plot korelasi silang antara $\alpha_{t}$ dan $\beta_{t}$

Berdasarkan plot korelasi silang antara deret input kurs dan deret output JII menunjukkan bahwa model fungsi transfer terbaik yaitu dengan nilai $b=0, s=0$, dan $r=0$ dengan nilai SBC sebesar -1317.75. Model untuk pendugaan parameter awal dari model fungsi transfer yaitu:

$$
Y_{t}=-2.6021 X_{t}
$$

Model fungsi transfer awal yang terbentuk adalah sebagai berikut:

$$
Y_{t}=-2.6021 X_{t}+n_{t}
$$

\section{G. Identifikasi Model ARIMA Deret Sisaan}

Perhitungan nilai $n_{t}$ diperoleh dengan cara melakukan transformasi terhadap model awalnya. Sehingga nilai $n_{t}$ diperoleh dengan persamaan sebagai berikut:

$$
n_{t}=Y_{t}+2.6021 X_{t}
$$

Model ARIMA(1,1,0) merupakan model sisaan terbaik karena semua parameter berbeda nyata dengan nol pada taraf nyata 0.05 dan memiliki nilai SBC yang paling 
kecil. Model untuk deret sisaan yang diperoleh yaitu:

$$
n_{t}=\frac{1}{(1-0.9995 B) \alpha_{t}}
$$

\section{H. Pendugaan Parameter Model Fungsi Transfer Akhir}

Identifikasi akhir model fungsi transfer dilakukan dengan mengkombinasikan model awal dan model sisaannya sehingga didapatkan model sebagai berikut:

$$
\begin{aligned}
Y_{t}= & 1.9955 Y_{t-1}-0.9955 Y_{t-2}-0.9590 X_{t} \\
& +1.9175 X_{t-1}-0.9585 X_{t-2}+\alpha_{t}
\end{aligned}
$$

Hasil pendugaan akhir model menunjukkan nilai $p$-value masing-masing dugaan parameter menunjukkan hasil yang nyata pada nilai taraf nyata 0.05 . Selain itu, tidak ada autokorelasi antar sisaan, dan korelasi deret input dengan sisaan tidak nyata pada nilai taraf nyata 0.05 , maka model tersebut ditetapkan sebagai model terbaik dan layak digunakan untuk peramalan.

\section{Peramalan}

Nilai MAPE hasil peramalan sebesar $0.6529 \%$ menunjukkan model fungsi transfer yang diperoleh cukup baik dalam melakukan peramalan.

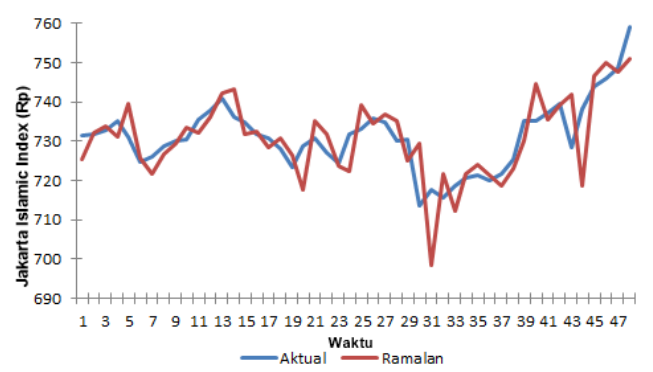

Gambar 5. Plot data aktual dengan data hasil peramalan data testing

\section{SIMPULAN}

Jakarta Islamic Index dapat dimodelkan dengan metode model fungsi transfer dengan deret input kurs. Berdasarkan model yang terbentuk, Jakarta Islamic Index dipengaruhi oleh Jakarta Islamic Index satu dan dua hari sebelumnya serta nilai kurs pada periode yang sama dan satu sampai dua hari sebelumnya. Nilai MAPE hasil peramalan sebesar $0.6529 \%$ menunjukkan model fungsi transfer yang diperoleh cukup baik dalam melakukan peramalan.

\section{SARAN}

Penulis menyarankan untuk mmelakukan pemodelan Jakarta Islamic Index dengan periode data mingguan atau bulanan sehingga tidak perlu melakukan pendugaan data kosong. Selain itu, dapat dilakukan penambahan peubah deret input seperti indeks saham asing untuk meningkatkan ketepatan prediksi pada model fungsi transfer.

\section{DAFTAR PUSTAKA}

BEI (2010). Jakarta Islamic Index. Bogor (ID): Bursa Efek Indonesia.

Cryer, J. dan K. Chan (2008). Time Series Analysis with Application in R. New York (US): Springer.

Montgomery, D. dan C. Jennings (2008). Introduction to Time Series Analysis and Forecasting. New Jersey (US): WileyInterscience.

Rusdi (2011). Uji Akar-akar Unit dalam Model Runtun Waktu Autoregresif. Jurnal Statistika 11, 67-68.

Wei, W. (2008). Time Series Analysis Univariate and Multivariate Methods. New York (US): Addison-Wesley.

Yulanda, L. (2006). Model Fungsi Transfer dengan Dua Peubah Penjelas [skripsi]. Bogor (ID): Institut Pertanian Bogor. 